\title{
Forum
}

PMLA invites members of the association to submit letters that comment on articles in previous issues or on matters of general scholarly or critical interest. The editor reserves the right to reject or edit Forum contributions and offers the PMLA authors discussed in published letters an opportunity to reply. Submissions of more than one thousand words are not considered. The journal omits titles before persons' names and discourages endnotes and works-cited lists in the Forum. Letters should be e-mailed to pmlaforum@ mla.org or be printed double-spaced and mailed to PMLA Forum, Modern Language Association, 26 Broadway, 3rd floor, New York, NY 10004-1789.

\section{Gaza and Lebanon in the Special Issue on War}

\section{To THE EDITOR:}

Given events over the past few years, PMLA's issue on war (124.5 [2009]) skirts two important locales: Lebanon and Gaza. A few noncommittal phrases (unattributed "violence in Jenin and in Bethlehem" [1768]; "[t]he rubble in Gaza still smoldered" [1886]) do no justice to these centers of war and tragedy in our time. While the essays range over wars from Troy to Afghanistan, the overall emphasis (despite critical sophistication and insights) exhibits inclusions and omissions typical of United States concerns and of "Western civilization" (a convenient, appropriative blend of Greek, Roman, and Judeo-Christian traditions). Could the cover photo, illustrating "the improvisational tactics of the disempowered [Nicaraguan "youthful Davids" in 1978] against the strategies and territorial control of the armed forces" (1501), have equally represented Palestinian youth today using bare hands and stones to confront United States-supported Israeli weapons of occupation? And why is Gaza not seen as today's Troy or Guernica?

Without the problem of Gaza and the larger Palestine, there would have been no United States (demonstrably Zionist-inspired) invasion of Iraq, as John J. Mearsheimer and Stephen M. Walt argue in The Israel Lobby and U.S. Foreign Policy (New York: Farrar, 2007; print; 229-62; see also 204-28). Nor would Al-Qaeda have much justifying rhetoric for its existence or ability to recruit fighters and launch attacks. Muslim fundamentalism, marginal two decades ago, has grown as a counter to Western interference and the absence of solutions for Palestine and other problems inflicted on the region, its doctrines more desperate because of continuous attacks on the region and conspiracy against its peoples. Following World War I, the so-called Middle East was carved into colonial spheres to prevent its ever gaining strength or real independence. The resultant countries

(C) 2011 BY THE MODERN LANGUAgE ASSOCIATION OF AMERICA 
have been structured to protect existing governments and vested foreign interests. Simultaneously, Israel, a political creation, was established in 1948 in Palestine, the region's land bridge. This creation translated imaginary biblical notions into realities on the ground, merging colonial logic with religious justification. Contrary to common assumption, colonialism did not disappear in the twentieth century. It lives in this region.

Gaza's overcrowded 1.8 million Palestinians are refugee survivors or descendants of survivors of the eviction in 1948 from coastal and southern parts of present Israel. Now they are imprisoned by an Israeli siege, unable to get sustenance or freedom and subjected to mass punishment. Other Palestinians wander the world, their rights and inheritance unacknowledged. This massive Nakba occurred so that Jews (mostly from Europe) could enter, train under British mandatory protection, and evict by force the original inhabitants, who were farming the land or living in cities. The Zionists claim return to a place they mythologize as given to them in covenant by a preferential god, a notion used earlier to justify colonial ventures in America, Australia, and South Africa-as shown in Michael Prior's The Bible and Colonialism (Sheffield: Sheffield Acad., 1997; print) and other works.

Instead of seeing mythology like the Zionists' as sourcing a tragic incubus, Srinivas Aravamudan's introduction (1505-14) cites narratives common to "Western civilization," paralleling (in a non sequitur) the myth of Rome's founding to "the endless wanderings of the Jews after their various expulsions" (1507). Aravamudan had an opportunity to see that his reference to "annihilating peoples, animals, and ecologies" is a model that derives from Old Testament narratives (1506-07). Mythologies of dispossession, religious monopolies, and ideas of a "chosen people" have been shown to be fallacious, based on earlier ignorance or racism, and now continued through calculated self-interest. Recent works that shed light on such issues include Thomas L. Thompson's The Mythic Past (London: Random, 1999; print), Shlomo Sand's The Invention of the Jewish People (London: Verso, 2010; print), and my Hidden Histories: Palestine and the Eastern Mediterranean (London: Pluto, 2010; print).

Anachronistic repetition of "the endless wanderings of the Jews" evades the fact that it is Palestinian natives who are wandering worldwide after their various expulsions or are imprisoned in the large concentration camps (ghettos) that are Gaza and the fragmented West Bank. While this war issue occasionally suggests how systems indoctrinate and deceive people, it omits a basic deception that has generated a justifying national myth some still believe is legitimate and god-approved.

Resistance to current hegemonies does not register much in this issue, which makes no reference to the epic Lebanese resistance to a superequipped Israeli army supported by the United States and complicit regional regimes. If there is any modern replica of the legend of the three hundred Spartans who fought the Persians at Thermopylae (recently depicted in a Hollywood film, 300, that exploited the ancient story of King Leonidas for contemporary antiIranian bias), it is a national group resisting occupation. Regardless of reservations about Islamic fundamentalism (though similar crazed fundamentalism acquires acceptance, even democratic legitimacy, in Jewish or Christian Zionism), the fact remains that in reporting current confrontations between local resisters and Israeli or Western occupiers mainstream media perceptions in the West downgrade such national resistance and make crass deception look like noble truth. Without resistance movements only compliant regimes would remain.

Nor is there reference in this issue to the wars waged by Israel using advanced and banned weapons (and deceptive publicity) - in the process massacring hundreds of children and civilians, recently killing unarmed solidarity members in a flotilla bringing aid to Gaza. There is no trace, even in "Harm's Way: Language and the Contemporary Arts of War" (1515-31), Mary Louise Pratt's admirable analysis of how language has been weaponized in Afghanistan and Iraq, of the media's and others' deceptions used in Israel's wars before and in 
2006 and 2008. Why did the language, to use Pratt's term, not "tremble" here (1516)?

Children's art in Gaza portrays the Israeli onslaught on that beleaguered strip as a Guernica. Subjecting Gazan civilians to bombardment methods even more savage than those used in Spain in 1937, Israel allows less than a bare subsistence level of food to enter Gaza and prevents Gazans from rebuilding homes and public structures.

Besieged refugee Gaza is a present Troy, an overpopulated and degraded copy of that glorious ancient city-Trojan horses the collaborators within working for its collapse, external forces relentless in attack. Its condition speaks of the divided nature of war and humanity. Gaza's future will tell if war is a perpetuity or if it is possible, in Aravamudan's words, to "mitigate its background conditions" in systems and people (1512).

Basem L. Ra'ad Al-Quds University

\section{Reply:}

The simplest response to Basem L. Ra'ad's letter is to plead guilty as charged, in that the special issue of $P M L A$ that I coedited with Diana Taylor can "do no justice to these centers of war and tragedy in our time [Lebanon and Gaza]." Nor was this collection intended to "do justice" to any other martial conflict that is under way. What piece of writing could do justice to a single war-related death, let alone the history of war throughout human civilization? While I respect and acknowledge that Ra'ad's concerns appear to come from genuine distress at a perceived absence of adequate representation, what is perhaps more troublesome about his unhappiness is the aspiration that representing Gaza as today's Troy or Guernica would have been an ennobling act on the part of this special issue. That kind of heroic celebration and commemoration of war is precisely what the issue sets out to avoid.

As I argue in my introduction to the issue, any approach to the perpetuity of war would need to engage "depictions of chivalric glory af- ter a war is over" as well as "the gory truths that such stories inevitably suppress" (1505). Unlike Troy or Guernica, the war in Gaza is ongoing and needs international attention. If epic is to be believed, Troy was sacked and burned to the ground, and the few remaining survivors fled. Picasso made his painting of the obliteration of Guernica by the Spanish Nationalists as a chilling reminder of war's devastation, revealed by the newfound horrors of aerial bombardment. What irony, therefore, that Picasso's Guernica, as the twentieth century's most famous antiwar statement, was painted in 1937, well before the worst atrocities of twentieth-century aerial bombardment! We can only multiply the ironies by reminding ourselves that the United Nations Security Council chamber in New York has a replica of Guernica on its walls and that this image was deliberately covered up during Colin Powell's infamous presentation before the Security Council arguing that he had concrete evidence of Saddam Hussein's possession of weapons of mass destruction, a prelude to the United States' illegal invasion of Iraq.

If every killing field and site of urban bombardment needs to achieve the status of Troy or Guernica to enter the field of literature or art, perhaps we need to rethink whether cultural representation and the theme of war should mix with each other at all. For every Troy immortalized through Homer and Vergil, how many ancient cities were destroyed with no bard to commemorate them? For every Guernica that stands as a sentinel against the horrors of aerial bombardment, how many Coventrys, Nanjings, Dresdens, Nagasakis, Ben Tres, and Gazas were bombed but without an adequate memento mori?

Even though Ra'ad's analysis of Middle Eastern conflict is simplistic, his desire for representation is not invalid. However, it is unfortunate that he has read my introduction's mention of "the endless wanderings of the Jews after their various expulsions" as a celebration and apology rather than as one of several examples of ancient cultural narratives linked to war, to which I add Gilgamesh, the Bhagavadgita, and Sun Tzu, none of which is an example of "Western civilization" 